\title{
Analyses of intermediate products during degradation of pyrene in soil by hemoglobin-catalyzed reaction
}

\author{
Haein Keum ${ }^{1,2} \cdot$ Guyoung Kang ${ }^{3}$ (D) \\ Received: 11 October 2018 / Accepted: 17 October 2018 / Published Online: 31 December 2018 \\ (C) The Korean Society for Applied Biological Chemistry 2018
}

\begin{abstract}
Hemoglobin ( $\mathrm{Hb})$ is a member of heme-protein that can perform catalytic non-specific chain reaction in the presence of hydrogen peroxide $\left(\mathrm{H}_{2} \mathrm{O}_{2}\right)$. Catalytic ability of $\mathrm{Hb}$ to degrade pyrene was demonstrated using soil contaminated with ${ }^{14} \mathrm{C}$ pyrene and $10 \mathrm{mg}$ pyrene $/ \mathrm{kg}$ soil. The composition of soil was similar to previously used soil except that it had lower organic carbon content. Bench scale laboratory tests were conducted in the presence of buffer only, $\mathrm{H}_{2} \mathrm{O}_{2}$ only, or $\mathrm{Hb}$ with $\mathrm{H}_{2} \mathrm{O}_{2}$ for $24 \mathrm{~h}$. After $24 \mathrm{~h}$ reaction, 0.1 and $1.3 \%$ of ${ }^{14} \mathrm{C}$ pyrene in contaminated soil were mineralized with $\mathrm{H}_{2} \mathrm{O}_{2}$ only or $\mathrm{Hb}$ plus $\mathrm{H}_{2} \mathrm{O}_{2}$. No mineralization to ${ }^{14} \mathrm{CO}_{2}$ was detected with buffer only. Approximately $12.2 \%$ of pyrene was degraded in the presence of $\mathrm{H}_{2} \mathrm{O}_{2}$ only while $44.0 \%$ of pyrene was degraded in the presence of $\mathrm{Hb}$ plus $\mathrm{H}_{2} \mathrm{O}_{2}$ during $24 \mathrm{~h}$ of catalytic reaction. When degradation intermediate products were examined, two chemicals were observed in the presence of $\mathrm{H}_{2} \mathrm{O}_{2}$ only while 25 chemicals were found in the presence of $\mathrm{Hb}$ plus $\mathrm{H}_{2} \mathrm{O}_{2}$. While most degradation products were simple hydrocarbons, four of the 27 chemicals had aromatic rings. However, none of these four chemicals was structurally related to pyrene. These results suggest that $\mathrm{Hb}$ catalytic system could be used to treat pyrene-contaminated soil as an efficient and speedy remediation technology. In addition, intermediate products generated by this system are not greatly affected by composition change in soil organic matter content.
\end{abstract}

Guyoung Kang $(\bowtie)$

E-mail: kanggy@hufs.ac.kr

${ }^{1}$ Department of Biosytems and Biotechnology, College of Life Sciences and Biotechnology, Korea University, Seoul 02841, Republic of Korea

${ }^{2}$ Chemical Safety Research Center, Korea Research Institute of Chemical Technology, Daejeon 34114, Republic of Korea

${ }^{3}$ Department of Environmental Science, Hankuk University of Foreign Studies, Youngin-si, Gyeonggi-do 17035, Republic of Korea

This is an Open Access article distributed under the terms of the Creative Commons Attribution Non-Commercial License (http://creativecommons. org/licenses/by-nc/3.0/) which permits unrestricted non-commercial use, distribution, and reproduction in any medium, provided the original work is properly cited.
Keywords Hemoglobin ' Hydrogen peroxide $\cdot$ Mass balance Pyrene $\cdot$ Remediation

\section{Introduction}

Polycyclic aromatic hydrocarbons (PAHs) are organopollutants that do not break down easily in the environment. PAHs are very hydrophobic. Thus, they are adsorbed onto non-aqueous entity of soil particles [1-2]. In addition, PAHs are composed of chemicals that are hard to be bioremediated. Among various means of remediation, bioremediation via microbes could be performed economically to decontaminate PAHs in soil [3-4]. For example, white rot fungus Phanerochaete chrysosporium can transform PAHs using various enzymes including extracellular enzymes. However, degradation of PAHs with over four benzene rings cannot be easily achieved by such treatments, leading to their persistence in the environment [5-6].

Among various PAHs, pyrene with four aromatic rings is one of the most persistent PAHs in the environment. Although it is not genotoxic, it is quite carcinogenic. It has been commonly used as an indicator to monitor PAHs contaminated soil [7]. Chemical and biological processes or technologies are nowadays preferred means for remediation of PAHs-contaminated sites [8-12].

Hemoglobin $(\mathrm{Hb})$ can efficiently oxidize organic chemicals such as PAHs. It is known that $\mathrm{Hb}$ can acts as a biocatalyst, similar to lignin peroxidases and other heme-containing peroxidases [1112]. Thus, organic radicals are generated during the catalytic cycle of $\mathrm{Hb}$ in the presence of $\mathrm{H}_{2} \mathrm{O}_{2}$. These organic radicals might participate in chemical reactions such as oxidation and polymerization, during which various intermediate products can be formed during detoxification of contaminants [10-15]. In our recent study with $\mathrm{Hb}$-catalyzed reaction, when pyrene in liquid solution is oxidatively removed, hydrophilic degradation intermediates are formed [15]. Thus, it is important to show that intermediates formed during the degradation process are less toxic or non-toxic 
$[2,16]$.

The objective of this study was to investigate intermediate products during degradation of pyrene in soil by hemoglobincatalyzed reaction. Especially, we aimed to examine degradation intermediates in another loam soil with lower organic carbon content than that used in our previous study [17].

\section{Materials and Methods}

\section{Soil preparation}

We collected loam soil from Mt. Eunbong in Hongchun of Kwangwon, Korea. In our previous study, we have confirmed that the area is not contaminated with organopollutant such as PAHs [17]. The property of the soil was found to be a sandy clay loam with $45 \%$ sand, $26 \%$ silt, $29 \%$ clay, organic carbon content of $9.9 \%$, and water holding capacity of $50 \%$. The soil was treated and prepared as described previously [17].

\section{Soil phase experiment}

The prepared soil $(2 \mathrm{~g})$ described above received $1 \mathrm{~mL}$ of pyrene stock solution (20 mg pyrene/L of acetonitrile) and $0.5 \mathrm{~mL}$ of ${ }^{14} \mathrm{C}$ pyrene. Pyrene stock solution was made with pyrene from AccuStandard (New Haven, CT, USA). The contaminated soil was then air-dried in the dark for 1 day. Initial pyrene concentration in soil was found to be $10.0 \mathrm{mg} / \mathrm{kg}$ by high pressure liquid chromatography (HPLC) analysis as described below. The extent of ${ }^{14} \mathrm{C}$ pyrene radioactivity in the soil was found to be $5,600,000$ $\pm 28,000$ disintegrations per min (dpm). Stock solutions of powder hemoglobin from bovine blood $(\mathrm{Hb})$ (Sigma-Aldrich Chemicals, St. Louis, MO, USA) were prepared with sodium phosphate buffer $(50 \mathrm{mM}, \mathrm{pH} 7.0)$. For control of $\mathrm{H}_{2} \mathrm{O}_{2}$ only, the stock solution received $\mathrm{H}_{2} \mathrm{O}_{2}$ in place of $\mathrm{Hb}$. For concomitant treatment with both $\mathrm{Hb}$ and $\mathrm{H}_{2} \mathrm{O}_{2}, \mathrm{H}_{2} \mathrm{O}_{2}$ was added to $\mathrm{Hb}$ stock solution.

A 40-mL grass vial with Teflon line cap was used as a reactor for pyrene degradation experiment. Two grams of pyrene-treated soil were treated with buffer only (control with buffer only), $0.06 \mathrm{~g} \mathrm{H}_{2} \mathrm{O}_{2}$ only (control with $\mathrm{H}_{2} \mathrm{O}_{2}$ only), or $0.02 \mathrm{~g} \mathrm{Hb}$ plus $0.06 \mathrm{~g} \mathrm{H}_{2} \mathrm{O}_{2}$ (i.e., treatment) as described previously [17]. The experiment was performed at room temperature $\left(25 \pm 2{ }^{\circ} \mathrm{C}\right)$. For all treatments, $50 \%$ water holding capacity was kept. Three trials were performed for every sample. Student's t test was used to compare difference between samples.

\section{Degradation of pyrene by hemoglobin-catalyzed reaction}

The extent of ${ }^{14} \mathrm{CO}_{2}$ evolution during treatment was measured by LS-6500 liquid scintillation counter (Beckman) as described previously [13-14]. After ${ }^{14} \mathrm{CO}_{2}$ evolution experiment, ${ }^{14} \mathrm{C}$ remaining in soil samples was extracted with dichloromethane for $24 \mathrm{~h}$ using Soxhlet procedure. The extracted solvent was concentrated to be solvent- exchanged with acetonitrile. The sample solvent was then concentrated to have a final volume of $2 \mathrm{~mL}$ for further analysis as follows. One $\mathrm{mL}$ of $2 \mathrm{~mL}$ solvent sample was used to measure ${ }^{14} \mathrm{C}$ extent of sample solvent by LS-6500 liquid scintillation counter. For the remaining soil after Soxhlet procedure, ${ }^{14} \mathrm{C}$ extent of solvent non-extractable minerals was determined [11,17].

\section{Pyrene degradation intermediates}

The other $1 \mathrm{~mL}$ of $2 \mathrm{~mL}$ sample solvent was subjected to HPLC. A part of HPLC eluent was used to measure the extent of radioactivity with a Beckman LS-6500 liquid scintillation counter $[13,14]$. The other part of HPLC eluent was extracted with hexane to be concentrated to $1 \mathrm{~mL}$ with a solvent concentrator. Mixture of the resulting $1 \mathrm{~mL}$ plus additional $15 \mathrm{~mL}$ acetonitrile was concentrated again to have a final volume of $200 \mu \mathrm{L}$ which was subject to gas chromatography mass spectrometry (GC/MS) analysis to obtain information of pyrene and its degradation intermediates as described previously [17].

\section{Results and Discussion}

Along with two controls, the treated soil received $10 \mathrm{mg}$ pyrene $/ \mathrm{kg}$ of soil and ${ }^{14} \mathrm{C}$ pyrene, after which it was subjected to treatment. Change in extent of ${ }^{14} \mathrm{CO}_{2}$ evolution for $24 \mathrm{~h}$ was measured for the two controls and soil treated with $\mathrm{Hb}$ and $\mathrm{H}_{2} \mathrm{O}_{2}$ (i.e., treatment) (Table 1). Control with buffer only showed no detectable ${ }^{14} \mathrm{CO}_{2}$ evolution. Control with $\mathrm{H}_{2} \mathrm{O}_{2}$ only showed $0.1 \%$ of ${ }^{14} \mathrm{CO}_{2}$ evolution. However, the soil treated with $\mathrm{Hb}$ and $\mathrm{H}_{2} \mathrm{O}_{2}$ had about $1.3 \%$ mineralization after $24 \mathrm{~h}$. In our previous study, we have shown that mineralization to ${ }^{14} \mathrm{CO}_{2}$ is not a major degradation reaction for soil treated with $\mathrm{Hb}$ and $\mathrm{H}_{2} \mathrm{O}_{2}$ [11,17]. To further trace down the fate of pyrene, mass balance study was performed by observing the extent of ${ }^{14} \mathrm{C}$ distribution among solvent and soil (Table 1 ). Extent of total ${ }^{14} \mathrm{C}$ radioactivity recovery for the soil treated with $\mathrm{Hb}$ plus $\mathrm{H}_{2} \mathrm{O}_{2}$ (i.e., $\mathrm{Hb}$-dependent catalytic reaction) was $67.9 \%$, among which 66.2 and $1.6 \%$ of radioactivity were found in acetonitrile solvent and soil phase, respectively. Thus, the total recovery for the soil treated with $\mathrm{Hb}$ and $\mathrm{H}_{2} \mathrm{O}_{2}$ was $69.1 \%$, including ${ }^{14} \mathrm{CO}_{2}$ gas phase. Total recoveries of ${ }^{14} \mathrm{C}$ radioactivity in the two controls were over 85.9 and $81.1 \%$ for control with buffer only and control with $\mathrm{H}_{2} \mathrm{O}_{2}$ only, respectively. Extent of total ${ }^{14} \mathrm{C}$ recovery decreased in the order of control with buffer only, control with $\mathrm{H}_{2} \mathrm{O}_{2}$ only, and soil treated with $\mathrm{Hb}$ and

Table 1 Mass balance analysis of pyrene-contaminated soil after $24 \mathrm{~h}$ of reaction*

\begin{tabular}{ccccc}
\hline \hline \multirow{2}{*}{ Treatment } & \multicolumn{4}{c}{ Extent (\%) of radioactivity in } \\
\cline { 2 - 5 } & Solvent** & Soil & ${ }^{14} \mathrm{CO}_{2}$ & Total \\
\hline Buffer only & $85.5 \pm 8.4$ & $0.4 \pm 0.0$ & $0.0 \pm 0.0$ & 85.9 \\
$\mathrm{H}_{2} \mathrm{O}_{2}$ only & $80.4 \pm 3.7$ & $0.6 \pm 0.1$ & $0.1 \pm 0.0$ & 81.1 \\
$\mathrm{Hb}+\mathrm{H}_{2} \mathrm{O}_{2}$ & $66.2 \pm 2.6$ & $1.6 \pm 0.0$ & $1.3 \pm 0.1$ & 69.1 \\
\hline
\end{tabular}

*Initially added radioactivity of ${ }^{14} \mathrm{C}$ pyrene was about $5,500,000 \mathrm{dpm}$. $* *$ Acetonitrile 


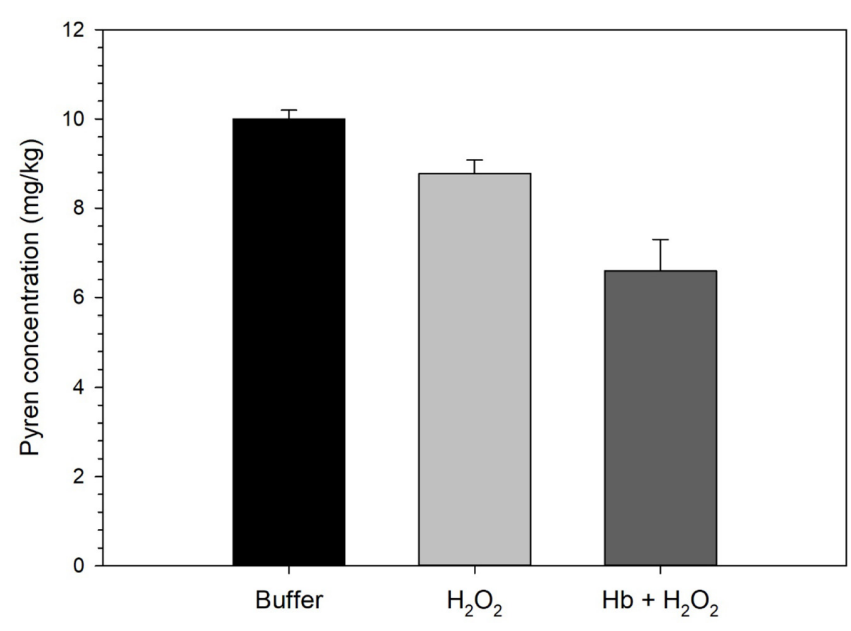

Fig. 1 Pyrene concentration after $24 \mathrm{~h}$ of hemoglobin catalytic reaction under different experimental conditions

$\mathrm{H}_{2} \mathrm{O}_{2}$ (Hb-dependent catalytic reaction). This result suggests that most pyrene and its degradation products in soil could be extractable with acetonitrile after $24 \mathrm{~h}$ of treatment with $\mathrm{Hb}$ dependent catalytic reaction. This kind of trend has been observed in our previous study [14]. We expected that pyrene, a carcinogenic component of PAHs, might be rapidly degraded by $\mathrm{Hb}$-dependent catalytic reaction. Upon treatment with $\mathrm{Hb}$ and $\mathrm{H}_{2} \mathrm{O}_{2}$, pyrene concentration was decreased from $10.0 \pm 0.2$ to $6.6 \pm 0.7 \mathrm{mg} / \mathrm{kg}$ soil, resulting in $44.0 \%$ of pyrene degradation in soil after $24 \mathrm{~h}$. In contrast, about $12.2 \%$ of pyrene was degraded for control with $\mathrm{H}_{2} \mathrm{O}_{2}$ only (Fig. 1). No degradation was observed for control with buffer only. These results indicate that treatment with $\mathrm{Hb}$ and $\mathrm{H}_{2} \mathrm{O}_{2}$ can be employed to remediate pyrene in soil and possibly other PAHs-contaminated soil. Of note, the catalytic activity of treatment with $\mathrm{Hb}$ and $\mathrm{H}_{2} \mathrm{O}_{2}$ is due to hemoglobin heme group that reacts with $\mathrm{H}_{2} \mathrm{O}_{2}$ to complete the catalytic cycle [10-14].

Acetonitrile solvent fractions from three different treatments were analyzed to observe pyrene and its degradation products (Fig. 2). HPLC eluent was collected every 1 min to measure the extent and distribution of radioactivity due to pyrene and its degradation products. Variations in the extent of absorbance and radioactivity for three treatments are shown in Fig. 2. Pyrene peaks at 13-14 min matched with radioactivity peak at 13-14 min. The size of pyrene peaks decreased in the sequence of control with buffer only, control with $\mathrm{H}_{2} \mathrm{O}_{2}$ only, and treatment with $\mathrm{Hb}$ and $\mathrm{H}_{2} \mathrm{O}_{2}$ (Hb-dependent catalytic reaction). We expected that degradation
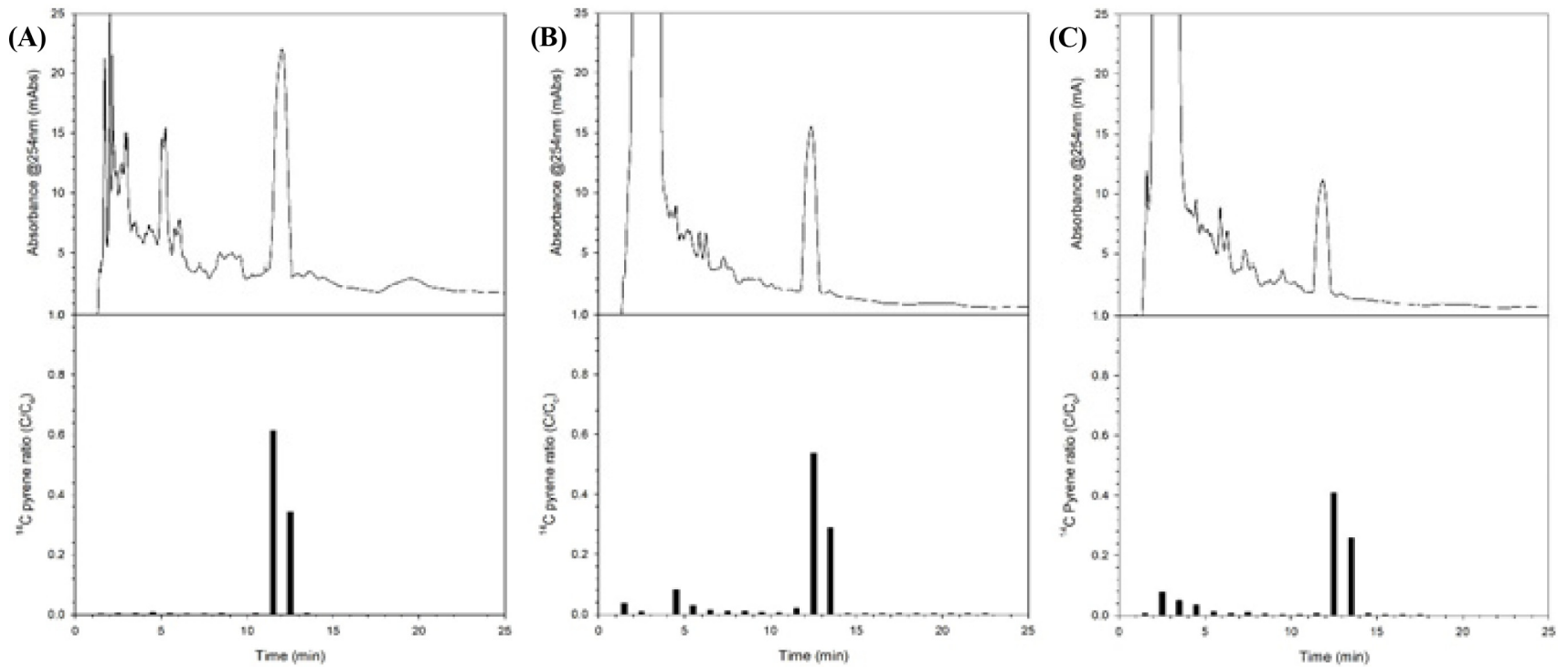

Fig. 2 HPLC chromatogram of acetonitrile extract after pyrene treatment with buffer only, $\mathrm{H}_{2} \mathrm{O}_{2}$ only, and with $\mathrm{Hb}$ plus $\mathrm{H}_{2} \mathrm{O}_{2}$

Table 2 GS/MS analyses of pyrene degradation products for control with $\mathrm{H}_{2} \mathrm{O}_{2}$

\begin{tabular}{lcl}
\hline \hline HPLC fraction time (min) & Compound name & Chemical structure \\
5 & 5-Methyl-1-phenyl-4-hydrocyclopenta[3,2-b] & Cyrrole
\end{tabular}


intermediates would appear before pyrene peaks at $13 \mathrm{~min}$ because intermediates are supposed to be less hydrophobic than pyrene. Some HPLC fractions having peaks of absorbance (254 $\mathrm{nm}$ ) and ${ }^{14} \mathrm{C}$ radioactivity were observed before $13 \mathrm{~min}$ for both control with $\mathrm{H}_{2} \mathrm{O}_{2}$ only and treatment with $\mathrm{Hb}$ and $\mathrm{H}_{2} \mathrm{O}_{2}$ (Fig. 2). It is currently unclear whether these two kinds peaks coincide due to complexity of the chromatogram.

We intended to examine pyrene degradation intermediate products in another loam soil with lower organic carbon content than that used in our previous study during Hb-catalyzed reaction. To identify what kind of degradation intermediates were produced for control with $\mathrm{H}_{2} \mathrm{O}_{2}$ only and treatment with $\mathrm{Hb}$ and $\mathrm{H}_{2} \mathrm{O}_{2}$, HPLC eluents were collected each $\mathrm{min}$ and analyzed by GC/MS to examine differentially specific chemicals produced for each treatment. In case of control with $\mathrm{Hb}$ only, no specific degradation product was observed. Table 2 reveals that two chemicals were observed at 5 and 13 min for control with $\mathrm{H}_{2} \mathrm{O}_{2}$ only. Table 3 revealed that 18 chemicals of mostly low molecular weight were observed until $12 \mathrm{~min}$. Some chemicals of high molecular weight were found at $13 \mathrm{~min}$. Table 3 revealed that 4 of 25 compounds had aromatic ring during $\mathrm{Hb}$-dependent catalytic reaction. Possible toxicity of these four aromatic chemicals was examined. However, none of these chemicals had noticeable carcinogenicity after we searched the database of toxic chemicals (SHEDS models, US EPA, Washington DC, USA). Additionally, these four chemicals with aromatic ring have no structural characteristics of pyrene, suggesting that they might not be directly derived from pyrene. Other chemicals are aliphatic hydrocarbons that might not

Table $3 \mathrm{GS} / \mathrm{MS}$ analyses of pyrene degradation products for treatment with hemoglobin and $\mathrm{H}_{2} \mathrm{O}_{2}$

\begin{tabular}{|c|c|c|c|c|}
\hline $\begin{array}{l}\text { HPLC fraction } \\
\text { time (min) }\end{array}$ & Compound name & Chemical structure & Chemical formula & Major ion $(\mathrm{m} / \mathrm{z})$ \\
\hline 3 & 3,6-Dimethyldecane & & $\mathrm{C}_{12} \mathrm{H}_{26}$ & 57 \\
\hline 3 & Tridecane & & $\mathrm{C}_{13} \mathrm{H}_{28}$ & 57 \\
\hline 3 & Pentadecane & & $\mathrm{C}_{13} \mathrm{H}_{32}$ & 57 \\
\hline 3 & 1-Nonadecene & & $\mathrm{C}_{19} \mathrm{H}_{38}$ & 57 \\
\hline 3 & 2-Methyl-octadecane & & $\mathrm{C}_{19} \mathrm{H}_{40}$ & 57 \\
\hline 3 & $\begin{array}{l}\text { 2,6,10,14,18-Pentamethyl-2,6,10,14,18- } \\
\text { eicosapentaene }\end{array}$ & & $\mathrm{C}_{25} \mathrm{H}_{42}$ & 69 \\
\hline 3 & Carbonic acid, eicosyl vinyl ester & & $\mathrm{C}_{23} \mathrm{H}_{44} \mathrm{O}_{3}$ & 57 \\
\hline 4 & Cetene & & $\mathrm{C} 16 \mathrm{H}_{32}$ & 41 \\
\hline 4 & 1,2-Benzenedicarboxylic acid, dibutyl ester & & $\mathrm{C}_{16} \mathrm{H} 22 \mathrm{O}_{4}$ & 149 \\
\hline 4 & Tricosane & & $\mathrm{C}_{23} \mathrm{H}_{48}$ & 57 \\
\hline 5 & 1-Octadecene & & $\mathrm{C}_{18} \mathrm{H}_{36}$ & 43 \\
\hline 5 & 7,9-Dimethylhexadecane & & $\mathrm{C}_{18} \mathrm{H}_{38}$ & 57 \\
\hline 6 & 1-Octadecanol & & $\mathrm{C}_{18} \mathrm{H}_{38} \mathrm{O}$ & 83 \\
\hline 9 & 2-Methyloctacosane & & $\mathrm{C}_{29} \mathrm{H}_{60}$ & 57 \\
\hline
\end{tabular}


Table 3 Continued

\begin{tabular}{|c|c|c|c|c|}
\hline $\begin{array}{l}\text { HPLC fraction } \\
\text { time (min) }\end{array}$ & Compound name & Chemical structure & Chemical formula & Major ion (m/z) \\
\hline 12 & 2-Methyldecane & & $\mathrm{C}_{11} \mathrm{H}_{24}$ & 43 \\
\hline 12 & 4,6-Dimethyldodecane & & $\mathrm{C}_{14} \mathrm{H}_{30}$ & 57 \\
\hline 12 & 1-Pentadecene & & $\mathrm{C}_{15} \mathrm{H}_{30}$ & 41 \\
\hline 12 & Pentatriacontane & & $\mathrm{C}_{35} \mathrm{H}_{72}$ & 57 \\
\hline 12 & Phosphonic acid, dioctadecyl ester & & $\mathrm{C}_{36} \mathrm{H}_{75} \mathrm{O}_{3} \mathrm{P}$ & 55 \\
\hline 13 & 2-Bromododecane & & $\mathrm{C}_{12} \mathrm{H}_{25} \mathrm{Br}$ & 57 \\
\hline 13 & 2,6,10,14-Tetramethylpentadecane & & $\mathrm{C}_{19} \mathrm{H}_{40}$ & 57 \\
\hline 13 & 1,2-Benzenedicarboxylic acid, dioctyl ester & & $\mathrm{C}_{24} \mathrm{H}_{38} \mathrm{O}_{4}$ & 149 \\
\hline 13 & $\begin{array}{l}\text { Iron, tricarbonyl[N-(phenyl-2-pyridinylmethylene) } \\
\text { benzenamine- } \mathrm{N}, \mathrm{N} \text { ']- }\end{array}$ & & $\mathrm{C}_{21} \mathrm{H}_{14} \mathrm{FeN}_{2} \mathrm{O}_{3}$ & 57 \\
\hline 13 & Tetratetracontane & & $\mathrm{C}_{44} \mathrm{H}_{90}$ & 57 \\
\hline 13 & Phthalic acid, butyl hexyl ester & & $\mathrm{C}_{18} \mathrm{H}_{26} \mathrm{O}_{4}$ & 149 \\
\hline
\end{tabular}

be toxic in general, especially at low concentration, indicating that there might be almost no toxic chemicals or residues remaining after treatment with $\mathrm{Hb}$ and $\mathrm{H}_{2} \mathrm{O}_{2}$. All these results are contrasted with previous studies in which numerous degradation intermediates of PAHs were observed [2,16]. Four additional chemicals such as 1-octadecanol, 2-methyloctacosane, pentatriacontane, and phthalic acid butyl hexyl ester were observed in the present intermediate analysis compared with previous analysis [17]. Of note, the two soils used for this present and previous studies had very similar soil texture, although they were different in organic content. Overall, only limited difference was observed in the number of observed chemicals possibly due to the difference in organic carbon content. Here, we found that a little bit more number and kind of organic intermediates were generated from soil with lower organic carbon content, possibly less interaction of reactive intermediates with organic matter.

Fenton reaction could be performed in aqueous systems as well as soil [18]. Hb-catalytic system could also be employed for degradation of pyrene in aqueous system and soil as shown in our previous study $[15,17]$. We also tried to investigate degradation product in soil with much lower organic content (i.e., $<10 \%$ ). However, it is very difficult to obtain soil with similar composition but with much less organic content. We also expect that different soil compositions might affect the process of organopollutnats. Regardless of organic content degradation, it is of some importance to have information on the kind of degradation intermediates because we need to have information on whether any hazardous intermediates are generated during the degradation process. 
Acknowledgments This research was supported by a grant (NRF2018R1D1A1B07049190) of the Basic Science Research Program through the National Research Foundation (NRF) funded by the Ministry of Education, Republic of Korea. This study was also partially supported by a grant of Hankuk University of Foreign Studies (2017).

\section{References}

1. Haritash AK, Kaushik CP (2009) Biodegradation aspects of polycyclic aromatic hydrocarbons (PAHs): a review. J Hazard Mater 169: 1-15

2. Peng RH, Xiong AS, Xue Y, Fu XY, Gao F, Zhao W, Tian YS, Yao QH (2008) Microbial biodegradation of polyaromatic hydrocarbons. FEMS Microbiol Rev 32: 927-955

3. Mohamed IAA, Khalil NM, El-Ghany MNA (2012) Biodegradation of some polycyclic aromatic hydrocarbons by Aspergillus terreus. African J Microbiol Res 6: 3783-3790

4. Luo S, Chen B, Lin L, Wang X, Tam NF, Luan T (2014) Pyrene degradation accelerated by constructed consortium of bacterium and microalga: Effects of degradation products on the microalgal growth. Environ Sci Technol 48: 391713924

5. Bumpus J (1989) Biodegradation of polycyclic aromatic hydrocarbons by Phanerochaete chrysosporium. Appl Environ Microbiol 55: 154-158

6. Hammel KE, Kalyanaraman B, Kirk TK (1986) Oxidation of polycyclic aromatic hydrocarbons and dibenzo[p]-dioxins by Phanerochaete chrysosporium ligninase. Biol Chem 261: 16948-16952

7. Cerniglia CE (1992) Biodegradation of polycyclic aromatic hydrocarbons. Biodegrad 3: 351-368

8. Sack U, Heinze TM, Deck J, Cerniglia CE, Artens RM, Zadrazil F, Fritsche W (1997) Comparison of phenanthrene and pyrene degradation by different wood-decaying fungi. Appl Environ Microbiol 63: 3919-
3925

9. Kanaly RA, Harayama S (2010) Advances in the field of highmolecular-weight polycyclic aromatic hydrocarbon biodegradation by bacteria. Microb Biotechnol 3: 136-164

10. Chung N, Park K, Stevens DK, Kang G (2014) Verification of heme catalytic cycle with 5-aminosalicylic acid and its application to soil remediation of polycyclic aromatic hydrocarbons. Environ Eng Res 19: 139-143

11. Kang G, Park K, Cho J, Stevens DK, Chung N (2015) Remediation of polycyclic aromatic hydrocarbons in soil using hemoglobin-catalytic mechanism. J Environ Eng 141: 04015025

12. Keum H, Kang G, Jho EH (2017) Optimization of hydrogen peroxide-tohemoglobin ratio for biocatalytic mineralization of polycyclic aromatic hydrocarbons (PAHs)-contaminated soils. Chemosphere 187: 206-211

13. Chen S, Stevens DK, Kang G (1999) Pentachlorophenol and crystal violet degradation in water and soils using heme and hydrogen peroxide. Wat Res 33: 3657-3665

14. Chen S, Stevens DK, Kang G, Hsieh MJ (2006) Treating soil PCP at optimal conditions using heme and peroxide. J Environ Eng ASCE 132: 704-708

15. Keum H, Kang G, Chung N (2017) Oxidation of pyrene using a hemoglobin-catalyzed biocatalytic reaction. Appl Biol Chem 60: 401405

16. Ghosal D, Ghosh S, Dutta TK, Ahn Y (2016) Current state of knowledge in microbial degradation of polycyclic aromatic hydrocarbons (PAHs): a review. Front Microbiol 7: 1369

17. Kang G, Lee S, Keum H, Chung N (2018) Degradation of pyrene contaminated soil with spiked ${ }^{14} \mathrm{C}$ pyrene by hemoglobin catalysis. Top Catal:10.1007/s11244-018-0960-z

18. Jung YS, Lim WT, Park JY, Kim YH (2009) Effect of pH on Fenton and Fenton-like oxidation. Environ Technol 30: 183-190 